\title{
Catch-up Growth in Cortisone-Treated Rats: Effects of Calcium and Vitamin D
}

\author{
I. MITCHELL, D. G. D. BARR, AND S. J. POCOCK \\ Royal Hospital for Sick Children, Edinburgh, Western General Hospital, Edinburgh, and Department of Child Life \\ and Health and the Medical Computing and Statistics Unit, University of Edinburgh, Edinburgh, Scotland
}

\begin{abstract}
Summary
The aim of the study was to develop an animal model of steroid stunting and catch-up growth and to investigate the possibility that calcium supplements, with or without vitamin D supplements, might mitigate the effects of corticosteroids on linear growth.

In the first experiment, newly weaned Wistar rats were allocated to four groups and weight and tail length measured weekly. In three groups cortisone was injected daily for 28 days. Two of the cortisone-treated groups were given calcium supplements daily in different dosage schedules. During cortisone treatment (Table 1), animals given cortisone gained less weight than the controls $(P<0.01)$. After cortisone was stopped the groups previously given cortisone showed greater weight gain than the controls $(P<0.01)$. Changes in tail length (Fig. 2$)$, representing changes in linear growth, showed that groups receiving cortisone grew less than the controls during cortisone treatment. After cortisone was stopped the control group grew less than the three groups that had previously received cortisone. There was no beneficial effect of supplemental calcium on either the degree of growth retardation or of catch-up growth (Tables 1 and 2).
\end{abstract}

A second experiment was performed to test the reproducibility of the method and to study the effects of calcium and vitamin D supplements on growth. Newly weaned rats were allocated to four groups. Three groups received cortisone for $\mathbf{4 2}$ days. Two of the cortisone-treated groups received vitamin $D$ once a week and one of these groups received calcium supplements. Weight and tail length velocities (Figs. 5 and 6 ) show less velocity than that of the cortisone-treated groups during cortisone treatment, and after cortisone was stopped the control group had lesser velocity. During cortisone treatment (Table 3), the control groups gained more weight than the three groups given cortisone $(P<0.001)$. After cortisone was stopped the groups previously receiving cortisone gained more weight than the control group $(P<0.01$ for cortisone alone and $P<0.001$ for cortisone and vitamin $D)$. Changes in mean tail lengths (Table 4) show that during cortisone treatment the three groups given cortisone alone, cortisone and vitamin $\mathrm{D}$, and cortisone, vitamin $D$, and calcium, all gained less than the controls $(P<\mathbf{0 . 0 0 1})$. After cortisone was stopped the groups previously treated with cortisone had a greater increase in tail length than the control groups $(P<0.001)$. The group given vitamin $D$ supplements grew more than the group given cortisone without such supplements $(P<0.01)$. The food consumed by the animals (g/100 g body wt/day) was measured (Fig. 7 ), and at no time did the control group eat more than the cortisone-treated groups. Reduced calorie intake was not the explanation for retardation of growth, and the increased food intake after cortisone was presumably necessary for catch-up. The serum calcium and total body calcium at the end of the experiment (Table 5) did not suggest that cortisone had depleted the skeleton of calcium.

The experiment confirmed that cortisone inhibits growth of total body weight and of tail length in newly weaned rats, but the total growth of all groups was similar by the end of the experiment and confirmed that catch-up growth had occurred. The groups given vitamin D supplements had a greater increase in tail length in the catch-up phase than the group given cortisone without such supplements. It may be that vitamin $D$ had a specific effect on the growth plate, ameliorating the effects of corticosteroids on growing cartilage.

\section{Speculation}

The growth retardation induced by cortisone may be partly related to direct effects on the skeleton. Vitamin $D$ may improve catch-up growth by antagonizing the effects of corticosteroids on the growth plate.

Retardation of linear growth is a major side effect of large doses of corticosteroids during childhood. There is evidence that this growth inhibition may be related to suppression of growth hormone secretion and/or interference with the metabolic actions of growth hormone, but the precise mechanisms of steroid stunting remain uncertain $(4,18,33)$.

Adrenal steroids have a marked catabolic effect on bone by reducing collagen synthesis and bone matrix formation (24), by increasing bone resorption (1), and by effects on mineral metabolism (11). The apparent antagonism of corticosteroids to vitamin $\mathrm{D}$ may be due to inhibition of normal cell transport mechanisms for calcium (16). Synthesis rates for various components of rat bone matrix are decreased by cortisone (6). Morphologic studies show that large doses of glucocorticoid suppress cell division in both bone and cartilage (17), and it has been suggested that glucocorticoids have a direct inhibitory effect on growing cartilage (7). Children on long-term corticosteroids may have retarded skeletal maturation (3) but the relationship between glucocorticoids, linear growth, bone age, and disease is complex (33).

The effects of corticosteroids on bone structure, mineral metabolism, and skeletal maturation might be particularly disadvantageous at periods when growth is normally rapid.

The completeness or otherwise of catch-up growth (23) after steroid stunting is difficult to assess in children because of the difficulty of separating the effects of treatment from the natural history of the underlying disease, which itself may be growth retarding.

The aim of the present study was therefore to develop, in young rats, an animal model of steroid stunting and catch-up growth, and to investigate the possibility that calcium supplements, with or without vitamin D supplements, might mitigate the effects of corticosteroids on linear growth and/or improve the prognosis for subsequent rehabilitation.

In the first experiment, a possible animal model was investigated and the effects of calcium supplements assessed. A second experiment was performed to test the reproducibility of the method and confirm that stunting and catch-up growth occurred with cortisone in the dose used, and to study the effects of calcium and vitamin D supplements on growth.

In both experiments, the growth of the animals was followed longitudinally by serial measurements of total body weight, and of tail length as an index of linear growth (9). In the second 
experiment, the food consumed by the animals was measured and related to the changes in growth, and an attempt was made to assess the metabolic status of the animals at the end of the study period by estimation of the serum calcium and total body content of calcium.

\section{MATERIALS AND METHODS}

\section{FIRST EXPERIMENT}

Forty-eight newly weaned Wistar rats were obtained commercially. They were weighed, tail length measured, and then alternate animals were allocated in order of decreasing weights to one of four groups. They were placed two per cage, without mixing the groups. A commercial animal diet (Laboratory diet 1; Spillers Limited, Suffolk), containing $2.4 \mathrm{IU}$ of vitamin $\mathrm{D}_{3}$ and $1.1 \mathrm{~g}$ of calcium $/ 100 \mathrm{~g}$ of food, and water were supplied ad libitum to each cage. The weight and tail length were measured twice weekly for five weeks, then weekly until the end of the experiment (13 weeks).

In three groups cortisone was injected ip daily, $2 \mathrm{mg} /$ day for 14 days, then $5 \mathrm{mg} /$ day for 14 days. For the same period sterile water was injected daily to the rats in the remaining group. Two of the cortisone-treated groups were given calcium supplements (atomic absorption spectroscopy) in the drinking water throughout the experiment in concentrations of 66 mmoles of calcium/liter of water and $132 \mathrm{mmoles}$ of calcium/liter.

\section{SECOND EXPERIMENT}

Forty-five newly weaned Wistar rats were obtained, measured (total body weight and tail length) as before, and allocated to four groups. The animals were in individual cages. Three groups received cortisone ip, $2 \mathrm{mg} /$ day for 14 days and $5 \mathrm{mg} /$ day for 28 days, and for the same period water was injected ip to the remaining group. Food and water were supplied ad libitum. Two of the cortisone-treated groups received $3000 \mathrm{IU}$ of vitamin D once a week by feeding tube throughout the experiment, and in addition one of these groups received calcium supplements in the water ( $46.5 \mathrm{mmoles}$ of calcium/liter) throughout the experiment. The food consumed by each animal was measured twice weekly. At 19 weeks blood was taken for estimation of serum calcium (acid digestion followed by atomic absorption spectroscopy) and the animals were killed. The total calcium content of the cadavers was measured (34).

\section{RESULTS}

\section{FIRST EXPERIMENT}

All animals in the control group survived. It was a condition of the licence permitting the experiment that those animals in which body weight fell more than $25 \%$ below that of the controls should be killed. Thus, of the animals given cortisone alone, three were killed; of those given cortisone and low-dose calcium supplements, six were killed; and of those given cortisone and the higher calcium supplement, five were killed. These animals were not included in the analysis.

Figures 1 and 2 show changes in mean total body weight and mean tail length for each group throughout the experiment. The groups given cortisone show retardation of growth in the latter period of treatment. After cortisone treatment, catch-up growth occurred for both body weight and tail length, although on the graphs this does not appear complete.

Table 1 shows a more detailed analysis of changes in weight. In the first 4 weeks, animals given cortisone gained less weight than the controls and the differences were statistically significant $(P<$ 0.01 ). In the period after cortisone was stopped (4-13 weeks), the groups previously given cortisone showed significantly greater weight gain than the controls $(P<0.01$ and $<0.05)$. For the whole period of the experiment ( $0-13$ weeks), the total gain in weight of the animals was similar and there were no statistically significant differences between the controls and the treated groups.

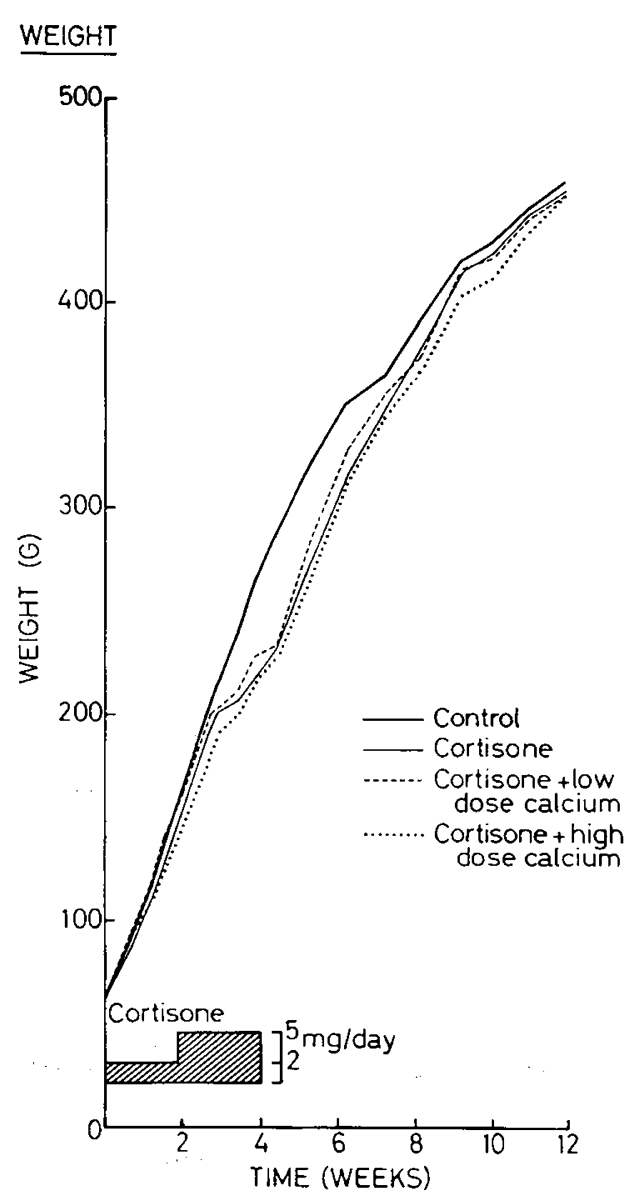

Fig. 1. Changes in mean body weight (first experiment).

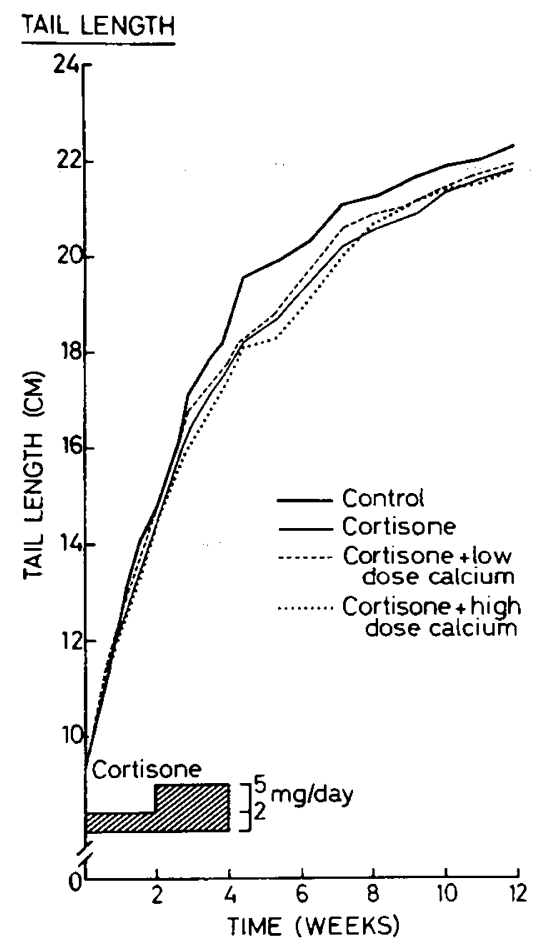

Fig. 2. Changes in mean tail length (first experiment).

Table 2 gives a similar analysis of the changes in tail length, representing changes in linear growth. The groups receiving cortisone grew less than the controls during cortisone treatment $(0-4$ weeks), and this was significantly less for the groups receiving cortisone alone and cortisone with high-dose calcium $(P<0.02$ 
Table 1. Mean increase in weight $(g \pm 1 S D)$

\begin{tabular}{lcccc}
\hline & & & \multicolumn{2}{c}{ Cortisone + calcium Cortisone + calcium } \\
& Controls $(n=12)$ & Cortisone $(n=9)$ & $(n=6)$ & \multicolumn{2}{c}{$\times 2(n=7)$} \\
\hline 0-4 weeks & $202.7 \pm 19.7$ & $157.7 \pm 10.6$ & $165.5 \pm 18.5$ & $155.1 \pm 16.5$ \\
Significance of difference from controls $(P)$ & & $<0.01$ & $<0.01$ & $<0.01$ \\
4-13 weeks & $196.5 \pm 28.7$ & $237.4 \pm 24.6$ & $227.2 \pm 26.8$ & $236.9 \pm 21.5$ \\
Significance of difference from controls $(P)$ & & $<0.01$ & $<0.05$ & $<0.01$ \\
0-13 weeks & $399.2 \pm 40.1$ & $395.1 \pm 21.0$ & $392.7 \pm 42.8$ & $392.0 \pm 29.9$ \\
Significance of difference from controls $(P)$ & & $\mathrm{NS}$ & $\mathrm{NS}$ & $\mathrm{NS}$ \\
\hline
\end{tabular}

Table 2. Mean increase in tail length $(\mathrm{cm} \pm I S D)$

\begin{tabular}{|c|c|c|c|c|}
\hline & Controls $(n=12)$ & Cortisone $(n=9)$ & $\begin{array}{l}\text { Cortisone }+ \text { calcium } \\
\quad(n=6)\end{array}$ & $\begin{array}{l}\text { Cortisone + calcium } \\
\quad \times 2(n=7)\end{array}$ \\
\hline $\begin{array}{l}0-4 \text { weeks } \\
\text { Significance of difference from controls }(P)\end{array}$ & $8.83 \pm 2.7$ & $\begin{array}{l}8.06 \pm 2.5 \\
<0.02\end{array}$ & $\begin{array}{l}8.28 \pm 2.5 \\
\text { NS }\end{array}$ & $\begin{array}{l}7.74 \pm 2.4 \\
<0.01\end{array}$ \\
\hline $\begin{array}{l}4-13 \text { weeks } \\
\text { Significance from difference from controls }(P)\end{array}$ & $4.15 \pm 0.5$ & $\begin{array}{l}4.27 \pm 0.5 \\
\text { NS }\end{array}$ & $\begin{array}{l}4.27 \pm 0.6 \\
\text { NS }\end{array}$ & $\begin{array}{l}4.59 \pm 0.4 \\
\quad \text { NS }\end{array}$ \\
\hline $\begin{array}{l}0-13 \text { weeks } \\
\text { Significance of difference from controls }(P)\end{array}$ & $12.98 \pm 3.1$ & $\begin{array}{l}12.32 \pm 2.9 \\
\mathrm{NS}\end{array}$ & $\begin{array}{l}12.55 \pm 3.1 \\
\mathrm{NS}\end{array}$ & $\begin{array}{l}12.33 \pm 2.3 \\
\mathrm{NS}\end{array}$ \\
\hline
\end{tabular}

and $<0.01$ ). After cortisone was stopped (4-13 weeks), the control group grew less than the three groups that had previously received cortisone, although the difference was not statistically significant. For the whole experiment (0-13 weeks), the total changes in tail length were similar for all of the animals, and there were no statistically significant differences between the controls and the treated groups.

\section{SECOND EXPERIMENT}

All rats survived to the end of the experiment.

Figures 3 and 4 show the changes in mean body weight and mean tail length, respectively, for each group. The three groups given cortisone show a lesser gain in body weight and lesser linear growth during cortisone treatment compared with the controls. After cortisone was stopped catch-up growth occurred in those groups previously treated with cortisone, but on the graphs the catch-up does not appear complete.

Figures 5 and 6 show the mean growth velocities for the total body weight and tail length. Mean weight velocity was calculated in fortnightly intervals as the difference in mean total body weight at the beginning and end of the fortnight, divided by 14 . A similar calculation was made for tail length velocity. The weight velocity (Fig. 5) was lower in the cortisone-treated groups compared with the controls in the early part of cortisone treatment. By the end of the cortisone treatment, the weight velocities of the control and cortisone-treated groups were similar. After cortisone was stopped the weight velocity of the groups previously receiving cortisone became greater than that of the controls and remained so until the end of the study. In Figure 6 the tail length velocities show similar changes.

Table 3 gives the detailed analysis of mean changes in weight gain. During cortisone treatment ( $0-6$ weeks) the control groups gained more weight than the three groups given cortisone, the difference being statistically significant $(P<0.001)$. There was no statistically significant difference between the two groups receiving cortisone and vitamin $D$ supplements and the group receiving cortisone without such supplements. After cortisone was stopped (6-19 weeks), the groups previously receiving cortisone gained more weight than the control group, and the differences were statistically significant $(P<0.01$ for cortisone alone and $P<0.001$ for cortisone and vitamin $\mathrm{D}$ ). The groups receiving cortisone along with vitamin $\mathrm{D}$ and calcium gained significantly more weight than the group receiving cortisone alone $(P<0.05)$. For the whole experiment ( $0-19$ weeks), the weight changes for all four groups were similar and there were no statistically significant differences between the control group and any of the treated groups.

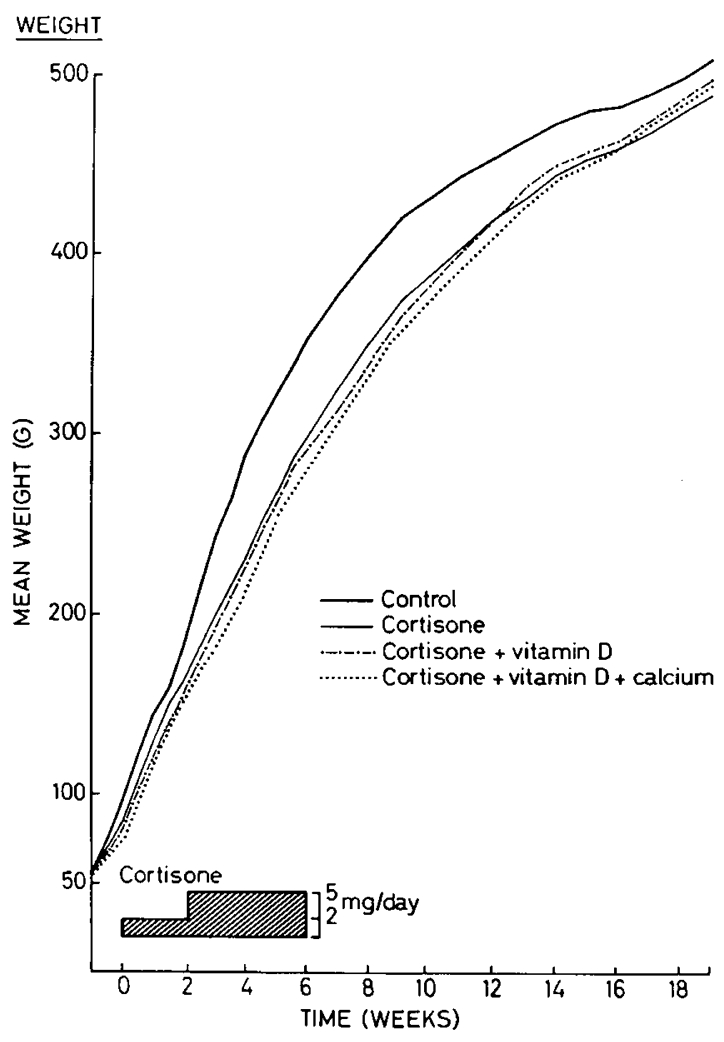

Fig. 3. Changes in mean body weight (second experiment).

Table 4 shows the same analysis for changes in mean tail lengths. During cortisone treatment (0-6 weeks), there is no statistically significant difference between the three treated groups, but all gained significantly less than the controls $(P<0.001)$. After cortisone was stopped (6-19 weeks), the two groups previously treated with cortisone and vitamin D had a statistically significant greater increase in tail length than the control group $(P<0.001)$ as did the group given cortisone alone $(P<0.05)$. The groups given vitamin $D$ supplements grew more than the group given cortisone without such supplements, and this was statistically significant $(P<0.01)$. The changes in tail length for the whole experiment (0-19 weeks) were similar for the treated and control groups, and there were no statistically significant differences between the groups. 


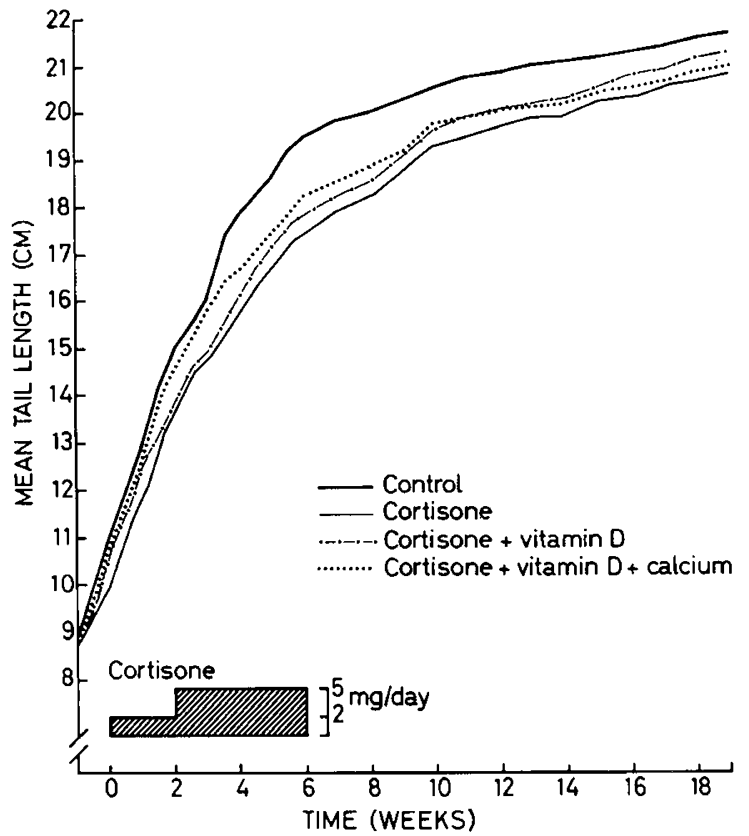

Fig. 4. Changes in mean tail length (second experiment).

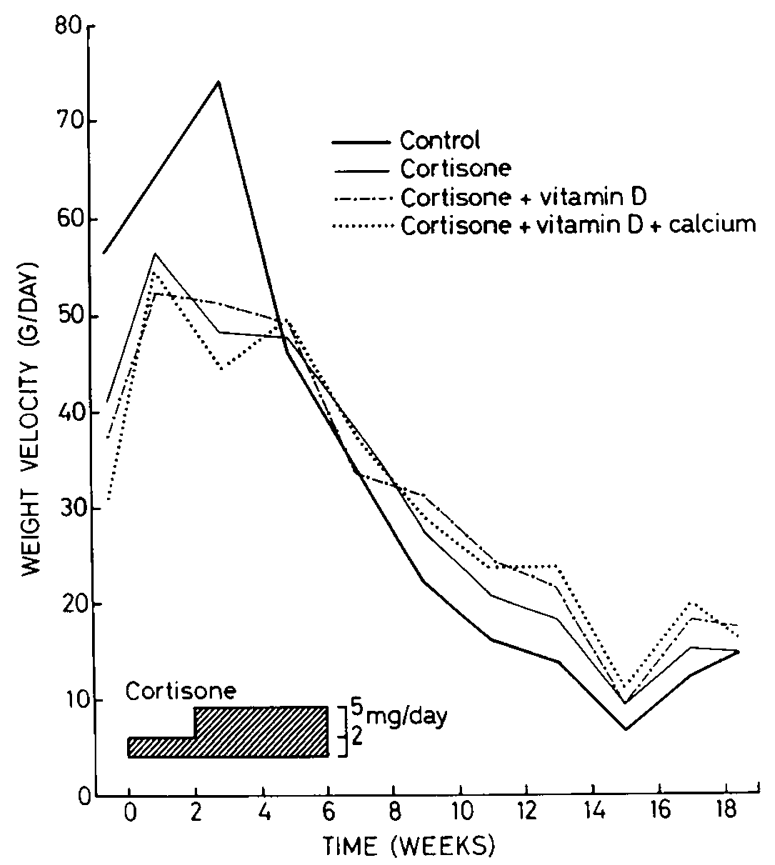

Fig. 5. Weight velocity (second experiment).

Table 5 gives the mean serum calcium concentrations and total body calcium content for all four groups at the end of the experiment. The three groups given cortisone with or without vitamin $\mathrm{D}$ supplements have higher mean serum calcium concentrations than the controls, and this difference is statistically significant $(P<0.05$ and $<0.025)$ for the groups given additional vitamin $\mathrm{D}$ along with calcium. The total body calcium is higher in the three groups given cortisone with and without vitamin D supplements than in the control group, and this difference is significant $(P<0.05)$ for the group given cortisone and vitamin D.

Figure 7 shows the mean variation in food intake for all four groups at five separate periods chosen with reference to the growth velocity curves (Figs. 5 and 6). To permit comparison of the food intake of animals of different sizes, the results are expressed as $g$ of food/100 g of body wt/day. In the first 2 weeks of cortisone treatment, there was no statistically significant difference in mean food intake between the control group and the treatment groups. At the end of cortisone treatment, the mean food intake per 100 $\mathrm{g}$ of body wt had fallen and the intake of the controls was less than all of the treatment groups, the difference being significant for the group receiving cortisone alone $(P<0.01)$ and the group receiving cortisone, vitamin $\mathrm{D}$, and calcium $(P<0.05)$. Two weeks after cessation of cortisone treatment, the food intake per unit body wt had fallen further for all four groups but was significantly smaller in the controls than in the groups treated with cortisone alone $(P<0.01)$, cortisone and vitamin D $(P<$ $0.02)$, and cortisone vitamin $\mathrm{D}$, and calcium $(P<0.05)$. In the fourth and fifth periods examined, the food intake per $100 \mathrm{~g}$ of body wt fell further for all four groups, and there was no statistically significant difference between the groups.

\section{DISCUSSION}

These experiments have confirmed that cortisone inhibits growth of total body weight and of tail length in newly weaned rats. In both experiments and for both measurements, the cortisone-treated groups all grew more than the control groups after cortisone was stopped. Thus, despite a period of growth lag, the total growth of all groups was similar by the end of the experiment, confirming that catch-up growth had occurred. In experiment 1 , the exclusion from the analysis of the animals with the most growth retardation, which had to be killed (see Results), introduces a bias that would tend to make the treatment groups appear less growth retarded and their catch-up more complete. The analysis of results for the remaining animals is valid however and comparable to the outcome in experiment 2.

The precise mechanisms of steroid stunting are not understood, nor are all of the factors which determine whether or not catch-up growth occurs. Cortisone has definite effects on the skeleton (30). In mice there is a decrease in size of chondrocytes and some proceed to cell death (26). In epiphysial cartilage of the rat, cortisone reduces the ability of chondrocytes to replicate and later to modulate to osteoblasts (27). In the brief epiphysial plate of rats, cortisone treatment led to a decrease in hydroxyapatite crystals and in calcium deposition (8). Cortisone does not produce bony rarefaction in rats and instead dense metaphysial bone develops (30). This is thought to occur because of failure of bone

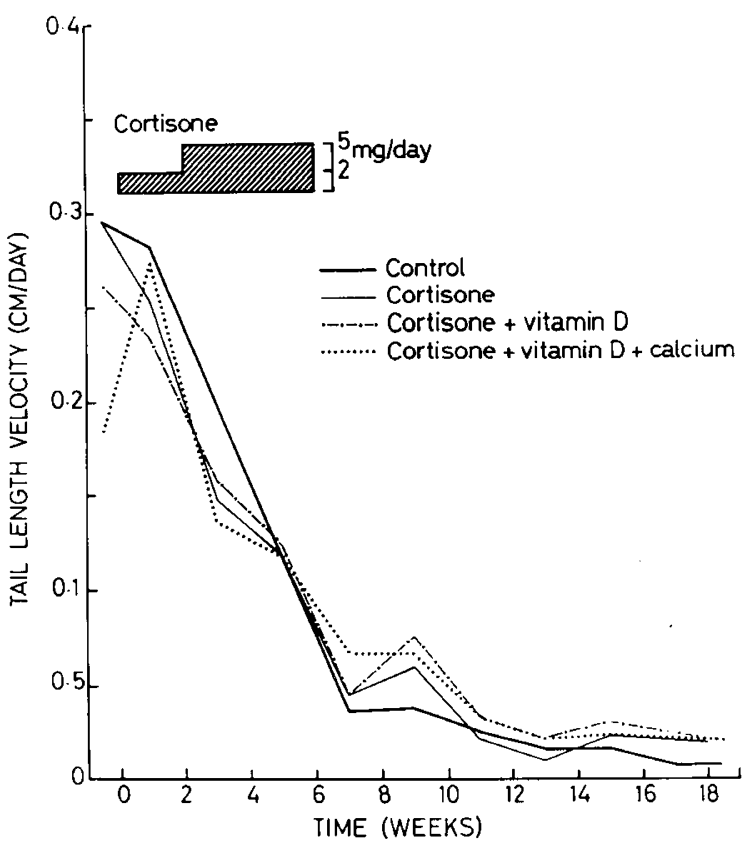

Fig. 6. Tail length velocity (second experiment). 
Table 3. Mean increase in weight $(g \pm 1 S D)$

\begin{tabular}{|c|c|c|c|c|}
\hline & Controls $(n=12)$ & Cortisone $(n=11)$ & $\begin{array}{c}\text { Cortisone + vitamin } \\
\mathrm{D}(n=11)\end{array}$ & $\begin{array}{l}\text { Cortisone }+ \text { vitamin } \\
\mathrm{D}+\text { calcium }(n=11)\end{array}$ \\
\hline $\begin{array}{l}0-6 \text { weeks } \\
\text { Significance of difference from controls }(P) \\
\text { Significance of difference from group given cortisone alone } \\
\quad(P)\end{array}$ & $257.7 \pm 21.2$ & $\begin{array}{l}212.9 \pm 23.8 \\
\quad<0.001\end{array}$ & $\begin{array}{l}212.3 \pm 30.8 \\
<0.001 \\
\quad \text { NS }\end{array}$ & $\begin{array}{l}207.9 \pm 23.6 \\
<0.001 \\
\text { NS }\end{array}$ \\
\hline $\begin{array}{l}\text { 6-19 weeks } \\
\text { Significance of difference from controls }(P) \\
\text { Significance of difference from group given cortisone alone } \\
\quad(P)\end{array}$ & $156.1 \pm 23.6$ & $\begin{array}{l}190.9 \pm 26.3 \\
\quad<0.01\end{array}$ & $\begin{array}{l}205.0 \pm 22.2 \\
<0.001 \\
\text { NS }\end{array}$ & $\begin{array}{l}213.5 \pm 26.7 \\
\quad<0.001 \\
\quad 0.05\end{array}$ \\
\hline $\begin{array}{l}0-19 \text { weeks } \\
\text { Significance of difference from controls }(P)\end{array}$ & $413.9 \pm 39.9$ & $\begin{array}{l}403.8 \pm 30.5 \\
\mathrm{NS}\end{array}$ & $\begin{array}{l}418.3 \pm 45.1 \\
\mathrm{NS}\end{array}$ & $\begin{array}{c}421.5 \pm 29.2 \\
\text { NS }\end{array}$ \\
\hline
\end{tabular}

Table 4. Mean increase in tail length $(\mathrm{cm}) \pm 1 S D)$

\begin{tabular}{|c|c|c|c|c|}
\hline & Controls $(n=12)$ & Cortisone $(n=11)$ & $\begin{array}{l}\text { Cortisone }+ \text { vitamin } \\
\qquad \mathrm{D}(n=11)\end{array}$ & $\begin{array}{l}\text { Cortisone }+ \text { vitamin } \\
\mathrm{D}+\text { calcium }(n=11)\end{array}$ \\
\hline $\begin{array}{l}0-6 \text { weeks } \\
\text { Significance of difference from controls }(P) \\
\text { Significance of difference from group given cortisone alone } \\
\quad(P)\end{array}$ & $8.41 \pm 0.7$ & $\begin{array}{c}7.26 \pm 1.0 \\
<0.01\end{array}$ & $\begin{array}{c}7.22 \pm 0.7 \\
<0.001 \\
\mathrm{NS}\end{array}$ & $\begin{array}{c}7.39 \pm 0.8 \\
<0.001 \\
\mathrm{NS}\end{array}$ \\
\hline $\begin{array}{l}\text { 6-19 weeks } \\
\text { Significance of difference from controls }(P) \\
\text { Significance of difference from group given cortisone alone } \\
\quad(P)\end{array}$ & $1.93 \pm 0.6$ & $\begin{array}{l}2.58 \pm 0.6 \\
<0.05\end{array}$ & $\begin{array}{l}3.31 \pm 0.5 \\
<0.001 \\
<0.01\end{array}$ & $\begin{array}{c}3.36 \pm 0.3 \\
<0.001 \\
<0.01\end{array}$ \\
\hline $\begin{array}{l}0-19 \text { weeks } \\
\text { Significance of difference from controls }(P)\end{array}$ & $10.34 \pm 0.8$ & $\begin{array}{c}9.85 \pm 1.5 \\
\mathrm{NS}\end{array}$ & $\begin{array}{l}10.53 \pm 1.1 \\
\mathrm{NS}\end{array}$ & $\begin{array}{c}10.75 \pm 0.9 \\
\text { NS }\end{array}$ \\
\hline
\end{tabular}

Table 5. Calcium (mean $\pm 1 S D$ ) at end of experiment

\begin{tabular}{|c|c|c|c|c|}
\hline & Controls $(n=12)$ & Cortisone $(n=11)$ & $\begin{array}{c}\text { Cortisone + vitamin } \\
\mathrm{D}(n=11)\end{array}$ & $\begin{array}{l}\text { Cortisone }+ \text { vitamin } \\
\mathrm{D}+\text { calcium }(n=11)\end{array}$ \\
\hline Serum calcium (mmole/liter) & $5.19 \pm 0.23$ & $5.34 \pm 0.21$ & $5.38 \pm 0.16$ & $5.36 \pm 0.25$ \\
\hline Significance of difference from controls $(P)$ & & NS & $<0.05$ & $<0.025$ \\
\hline Total body calcium (mmole $/ \mathrm{kg}$ ) & $346.08 \pm 74.0$ & $379.27 \pm 62.1$ & $405.45 \pm 84.7$ & $358.30 \pm 27.2$ \\
\hline Significance of difference from controls $(P)$ & & NS & $<0.05$ & NS \\
\hline
\end{tabular}

resorption rather than increased bone formation. Rarefaction does occur in rats with cortisone, however, when they are calcium depleted (29).

Rats absorb up to $98 \%$ of dietary calcium (12) and this is only slightly reduced in the intact animal by cortisone (31). In our first experiment there was no beneficial effect of supplemental calcium on either the degree of growth retardation or of catch-up growth (Figs. 1 and 2).

We have shown (Table 4) that the groups given vitamin D supplements had significantly greater increase in tail length in the catch-up phase than the group given cortisone without such supplements. The serum calcium and total body calcium of the animals at the end of the second experiment (Table 5) do not suggest that cortisone had depleted the skeleton of calcium. Indeed, the mean serum calcium and mean total body calcium of all three groups treated with cortisone were greater than those of the control. These measurements were all made at the end of the experiment and do not necessarily reflect dynamic changes during the study. It is unlikely, in view of the high absorption of calcium from the gut of the rat, that the effect of vitamin $D$ in counteracting steroid-induced growth retardation is related to improved intestinal absorption. It may be that vitamin $D$ in our animals had a more specific effect on the epiphysial growth plates, perhaps by ameliorating the inhibitory effects of corticosteroids on the maturation and calcification of growing cartilage.
Malnutrition in children (2) and in rats (32) leads to growth retardation and catch-up may occur later, depending on the timing, duration, and degree of malnutrition. In our study the caloric intake of the animals was measured as reflected by food consumed throughout the second experiment (Fig. 7) at periods chosen with respect to the growth velocity curves (Figs. 5 and 6). At the beginning of cortisone therapy, there was no statistically significant difference in the food intake per unit body weight. Toward the end of the cortisone treatment the food intake, on a unit body weight basis, of the three treated groups was greater than the controls, and this difference became statistically significant. Toward the end of the study, the food intake per $100 \mathrm{~g}$ of body weight of all four groups fell and there was no statistically significant differences between the groups. Thus, at no time did the control animals eat more per unit body weight than the cortisone-treated groups, suggesting that reduced caloric intake was not the explanation for the retardation of weight gain and linear growth in animals on cortisone. Indeed, the cortisonetreated groups ate more than the controls in the latter part of cortisone treatment and in the early part of the recovery phase. The increased food intake of the treated groups during these periods was presumably necessary to allow for the catch-up growth.

Although the effects of cortisone on the skeleton may contribute to the growth retardation, many other factors may be involved 

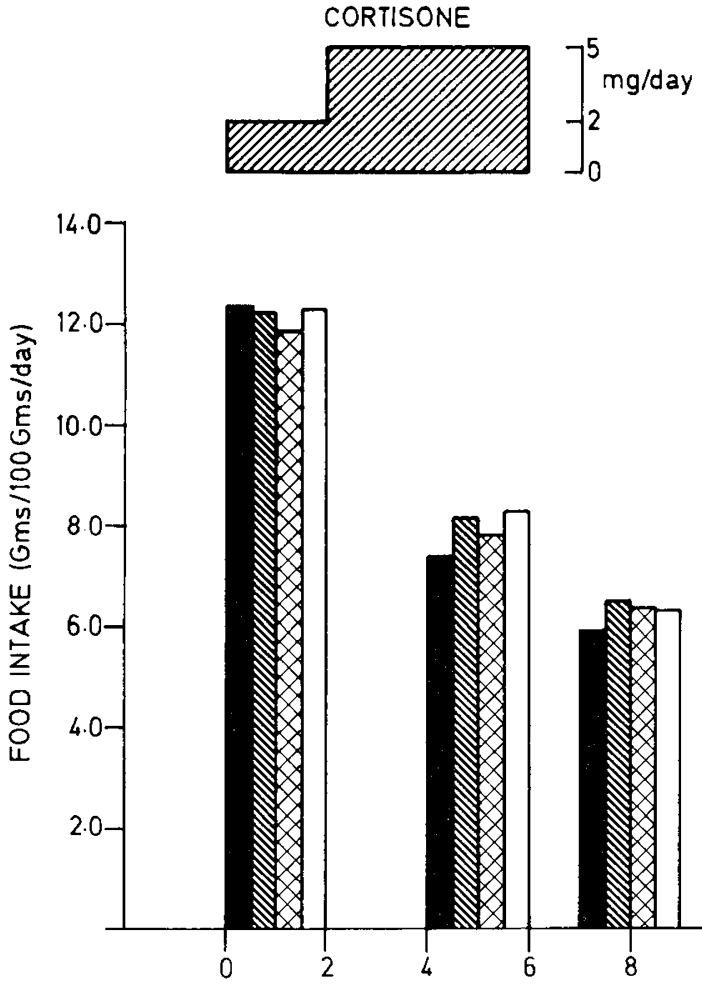

Fig. 7. Mean food intake ( $\mathrm{g}$ of food/100 $\mathrm{g}$ of body weight/day) at five periods.

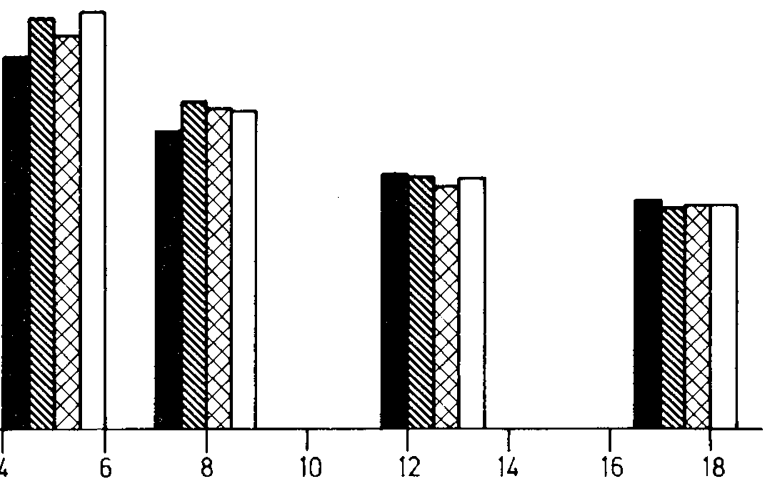

TIME (WEEKS)

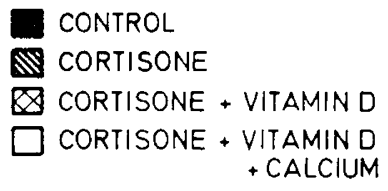

+ CALCIUM

including the effects on growth hormone $(15,21,25)$, nitrogen balance (5), and calcium balance (19). In rats, although corticosteroids increase the amount of growth hormone in the pituitary, growth hormone release after insulin hypoglycaemia is impaired (22) and there may be peripheral antagonism of the effects of growth hormone by corticosteroids (28).

The results we obtained might have been different with other corticosteroids, alternative dosage schedules, or a different duration or timing of treatment. Although there are variations in pharmacologic actions of corticosteroids, all have some growth suppressive effect (13). In rats, dose-dependent effects have been demonstrated in the actions of corticosteroids of bone (14) and on the growth of body, brain, and thymus (10). We used approximately $24 \mathrm{mg}$ of cortisone $/ \mathrm{kg}$ of body weight/day at the start of the experiment and increased the dose after 2 weeks, but made no attempt to maintain a constant dosage on a body weight basis.

The final outcome in steroid stunting may depend on the duration of follow-up. Full catch-up after early malnutrition in rats was demonstrated (32) when measurements were continued until growth ceased at about 32 weeks of age. Less prolonged studies showed failure of rats to compensate for cortisone-induced growth retardation (20). The long-term deleterious effect on growth in children arises from the disproportionate effect of corticosteroids on velocity oi linear growth and skeletal maturation. Methods exist for measuring bone age in rats (32), and, although we did not do this, the shape of the growth curves suggests that further maturation and linear growth in our animals might have been possible.

\section{CONCLUSION}

The results obtained suggest a useful animal model for the study of steroid stunting and subsequent catch-up growth. Vitamin D had no demonstrable effect on growth during steroid treatment, but improved the potential for growth after corticosteroids were stopped. In view of the known efficiency of calcium absorption in rats and the reported absence of osteoporosis after the use of steroids in this species, it is unlikely that the vitamin D effect on growth in our animals was mediated through any improvement in the absorption of calcium or effects on overall mineral balance. In cortisone-treated rats, vitamin $\mathrm{D}$ may have a specific action on the growth plate, facilitating maturation of cartilage and growth of the skeleton.

The effect of vitamin D described in this study cannot, however, be directly applied to patients because of the species to species variation in the skeletal effects of cortisone.

\section{REFERENCES AND NOTES}

1. Avioli, C. V., Birge, S. T., and Lee, S. W.: Effects of prednisolone on vitamin D metabolism in man. J. Clin. Endocrinol., 28: 1341 (1968).

2. Barr, D. G. D., Shmerling, D. H., and Prader, A.: Catch-up growth in malnutrition, studied in celiac disease after institution of gluten-free diet. Pediatr. Res., 6: 521 (1972).

3. Blodgett, F. M., Burgin, L., Iezzoni, D., Gribetz, D., and Talbot, N. B.: Effects of prolonged cortisone treatment on the statural growth, skeletal maturation and metabolic status of children. N. Engl. J. Med., 254: 636 (1956).

4. British Medical Journal (leading article): Corticosteroid therapy and growth. 1 : 393 (1969).

5. Cannon, P. R., Frazier, L. E., and Hughes, R. H.: The influence of cortisone upon protein metabolism. Arch. Pathol., 61: 271 (1956).

6. Cruess, R. L., and Sakai T.: Effect of cortisone upon synthesis rates of some components of rat bone matrix. Clin. Orthop. Relat. Res., 86: 253 (1972).

7. Daughaday, W. H., Herington, A. C., and Philips, L. S.: The regulation of growth by endocrines. Am. Rev. Physiol., 37: 211 (1975).

8. Dearden, L. C., and Espinosa, T.: Comparison of mineralization of the tibial epiphyseal plate in immature rats following treatment with cortisone, propylthiouracil or after feeding. Calc. Tissue Res., 15: 93 (1974)

9. De Groot, D. A.: Tail growth in the thyroxine-treated hypophysectomized rat as a sensitive criterion for growth hormone activity. Acta Endocrinol., 42: 423 (1963).

10. De Souza, S. W., and Adlard, B. P. F.: Growth of suckling rats after treatment with dexamethasone or cortisone. Arch. Dis. Child., 48: 519 (1973)

11. Epstein, F. H.: Calcium and the kidney. Am. J. Med., 45: 700 (1968).

12. Fairbanks, B. W., and Mitchell, H. H.: The relation between calcium retention and the store of calcium in the body, with particular reference to the determination of calcium requirements. J. Nutr., 11:551 (1936).

13. Falliers, C. J., Tan, L. S., Szentivanyi, J., Jorgensen, J. R., and Bukentz, S. C.: 
Childhood asthma and steroid therapy as influences on growth. Am. J. Dis. Child., 105: 127 (1963).

14. Follis, R. H.: The effect of cortisone on the growing bones of the rat. Proc. Soc. Exp. Biol., 88: 440 (1951).

15. Hartog, M., Gaafar, M. A., and Fraser, R.: Effect of corticosteroids on serum growth hormone. Lancet, 2: 376 (1964)

16. Kimberg, D. V., Boerg, R. D., Gershorn, E., and Grandusius, R. T.: Effect of cortisone treatment on the active transport of calcium by the small intestine. $J$. Clin. Invest., 50: 1309 (1971).

17. Leung, K., and Munck, A.: Peripheral actions of glucocorticoids. Ann. Rev. Physiol., 37: 246 (1975)

18. Loeb, J. N.: Corticosteroids and growth. N. Engl. J. Med., 295: 547 (1976).

19. Manson, G., and Johnston, J. A.: Studies in rheumatic fever. IV. Attempts to offset the calcium losses incidental to steroid therapy. Am. J. Dis. Child., 109: 483 (1965).

20. Mosier, H. D.: Failure of compensatory (catch-up) growth in the rat. Pediatr. Res., 5: 59 (1971).

21. Pantelakis, S. N., Sinaniotis, C. A., Sbirakis, S., Ikkos, D., and Doxiadis, S. A.: Night and day growth hormone levels during treatment with corticosteroids and corticotrophin. Arch. Dis. Child., 47: 605 (1972).

22. Pecile, A., and Müller, E.: Suppressive action of corticosteroids on the secretion of growth hormone. J. Endocrinol., 36: 401 (1966).

23. Prader, A., Tanner, J. M., and von Harnack, G. A.: Catch-up growth following illness or starvation. J. Pediatr., 62: 646 (1963).

24. Prockop, E. J., and Kivirikko, A. I.: Hydroxyproline in the metabolism of collagen. In: B. S. Gould and G. N. Ramachandran: Treatise on Collagen, p. 261 (Academic Press, New York, 1968).

25. Root, A. W., Bongiovanni, A. M., and Eberhein, W. R.: Studies of the secretion and metabolic effects of human growth hormone in children with glucocorticoid-induced growth retardation. J. Pediatr., 75: 826 (1969)

26. Silberberg, M., Silberberg, R., and Hasler, M.: Fine structure of articular cartilage of mice receiving cortisone acetate. Arch. Pathol., 82: 569 (1966).

27. Simmons, D. J., and Kunin, A. S.: Autoradiographic and biochemical investigations of the effect of cortisone on bones of the rat. Clin. Orthop. Relat. Res., 55: 201 (1967)

28. Soyka, L. F., and Crawford, J. D.: Antagonism by cortisone of the linear growth induced in hypopituitary patients and hypophysectomized rats by human growth hormone. J. Clin. Endocrinol., 25: 469 (1965).

29. Storey, E.: Bone changes associated with cortisone administration in the rat: Effect of variations in dietary calcium and phosphorus. Br. J. Exp. Pathol., 41 207 (1960).

30. Storey, E.: The influence of adrenal cortical hormones on bone formation and resorption. Clin. Orthop. Relat. Res., 30: 197 (1963).

31. Williams, G. A., Bowser, E. N., Henderson, W. J., and Uzgiris, V.: Calcium absorption in the rat in relation to excessive Vitamin D and cortisone. Proc. Soc. Exp. Biol. Med., 110: 889 (1962).

32. Williams, J. P. G., Tanner, J. M., and Hughes, P. C. R.: Catch-up growth in male rats after growth retardation during the suckling period. Pediatr. Res., 8: 149 (1974).

33. Zachmann, M.: Long-term corticosteroid treatment during childhood. Effects on growth and adrenal function. Paediatrician, 2: 188 (1973).

34. The assistance of Mr. J. Thompson, Biochemist, Clinical Chemistry, Western General Hospital, Edinburgh, who performed the chemical analysis is gratefully acknowledged.

35. Received for publication December 16, 1977.

36. Accepted for publication January 27, 1978. 